\title{
PENDAMPINGAN USAHA PETERNAKAN SAPI PERAH MANDIRI DI DESA PESANGGRAHAN PINGGIRAN KOTA BATU JAWA TIMUR
}

\author{
M. Farid Wadjdi'), Usman Ali'1) \\ 1)Program Studi Peternakan, Fakultas Peternakan, Universitas Islam Malang, Jawa Timur, Indonesia \\ Corresponding author : Usman Ali \\ E-mail :usmn.ali@unisma.ac.id
}

Diterima 27 Oktober 2021, Disetujui 05 November 2021

\begin{abstract}
ABSTRAK
Program Pengabdian Masyarakat bertujuan untuk meningkatkan pengetahuan dan keterampilan peternak berbagai aspek produksi dan manajemen peternakan intensif mengacu pada sapta usaha peternakan agar produksi dan kualitas susu serta pendapatan peternak meningkat. Beberapa permasalahan yang dihadapi mitra yaitu 1). Sulitnya pengadaan bahan pakan terutama hijauan berkualitas dan kurang kuantitasnya, 2). Formulasi pakan konsentrat tidak memenuhi standart nutrisi berakibat produksi susu tidak optimal, 3). Rasio penggunaan hijauan dan konsentrat dalam pakan TMR tidak memenuhi kebutuhan nutrisi perlu ditambah pakan suplemen UMB kaya makromineral, 4). Manajemen pemeliharaan belum intensif. Kemudian tim pengabdi menawarkan solusi melakukan kegiatan, 1). Penyiapan pakan berkualitas dengan formulasi pakan TMR untuk meningkatkan produksi, kualitas susu dan pendapatan 2). Pembinaan manajemen pemeliharaan intensif melalui penyuluhan dan pendampingan usaha peternakan mengacu sapta usaha peternakan 3). Melakukan pelatihan fermentasi limbah agroindustri menjadi pakan berkualitas, 4). Pendampingan pembuatan pakan suplemen Urea molasses bloks kaya makromineral. Hasil yang dicapai, tim pengabdi telah melaksanakan beberapa kegiataan menggunakan metode penyuluhan pemahaman sapta usaha peternakan, Demo praktek fermentasi pakan menjadi berkualitas dan palatabel, pembuatan pakan jilat UMB sebagai pakan suplemen, serta pendampingan usaha menggunakan pakan TMR rasio konsentrat $40 \%$ dan hijauan $60 \%$ dalam BK. Disimpukan bahwa semua kegiatan yang telah dilakukan direspon peternak dengan baik dan tetap dibuka konsultasi untuk pengembangan peternakan sapi perah..
\end{abstract}

Kata kunci: pakan jilat UMB plus; pakan TMR; sapta usaha peternakan

\begin{abstract}
The Community Service Program aims to improve the knowledge and skills of farmers in various aspects of production and management of intensive livestock farming, which refers to livestock business so that milk production and quality as well as farmers' incomes increase. Some of the problems faced by partners are 1). The difficulty of procuring feed ingredients, especially quality forage and lack of quantity, 2). Concentrated feed formulations do not meet nutritional standards resulting in suboptimal milk production, 3). The ratio of the use of forage and concentrate in the TMR feed does not meet the nutritional needs, it is necessary to add a macromineral-rich UMB supplementary feed, 4). Maintenance management has not been intensive. Then the service team offers solutions to carry out activities, 1 ). Preparation of quality feed with TMR feed formulations to increase production, milk quality and income 2). Intensive maintenance management development through counseling and assistance for livestock business refers to the Sapta livestock business 3). Conduct training on fermentation of agro-industrial waste into quality feed, 4). Assistance in the manufacture of macromineral rich Urea molasses block feed supplements. The results achieved, the service team has carried out several activities using the method of counseling the understanding of animal husbandry, demonstration of the practice of fermenting feed to become quality and palatable, making UMB lick feed as supplementary feed, as well as business assistance using TMR feed with a concentrate ratio of $40 \%$ and forage $60 \%$ in BK. It was concluded that all the activities that had been carried out were responded to by the farmers well and consultations were still open for the development of dairy farms.
\end{abstract}

Keywords: UMB plus lick feed, TMR feed, livestock business

\section{PENDAHULUAN}

Mitra program pengabdian masyaraka

(PPM) ini merupakan peternak sapi perah mandiri di Desa Pesanggrhan pinggiran Kota Batu Jawa Timur yang menggunakan sistem semi intensif berlantai plester dan perkawinan 
inseminasi buatan (IB), semua ternak dikandangkan koloni dan khusus sapi bunting tua dilakukan exercise bertujuan memperlancar proses partus, pemberian pakan menggunakan hijauan pakan unggul seperti rumput gajah dan daun leguminosa yang dikombinasikan tebon jagung ditambah konsentrat yang diformulasi sendiri. Pemberian pakan sebaiknya mengikuti pedoman rasio hijauan $60 \%$ dan konsentrat $40 \%$ bentuk bahan kering (Adibul dan Usman, 2021) atau pemberian hijauan sebanyak $10 \%$ bobot badan (BB) dan pemberian konsentrat sebanyak 1-2 \% Bobot Badan ternak ruminansia (Usman, 2017)

Hasil reobservasi tim pengabdi terkini pada Juni 2021, mitra peternak sapi perah bapak Mukib mempunyai sapi induk laktasi 8 ekor, bunting tua 3 ekor, sapi dara 4 ekor dan pedet 3 ekor, dalam kandang kelompok meliputi kandang pedet, kandang dara dan kandang laktasi tanpa diikat pola pemberian pakan dan manajemen pemeliharaan relatif sama. Ternak dikandangkan individual tanpa sekat dengan lantai cor pelester dan tidak dibuatkan palungan pakan hanya berupa lantai plester di depan sapi sebagai tempat hamparan hijauan pakan yang telah dicampur konsentrat sedang tempat minum berupa bak air yang dipindah, selanjutnya di bagian belakang kandang dilengkapi saluran pembuangan feses dan urin dibuang ke sungai tercampur pembuangan kotoran sapi perah. Hal ini akan mencemari aliran air di sungai yang dapat mencemari lingkungan dan kesehatan masyarakat.

Pola pemberian pakan menggunakan pakan TMR (total mixed ration) yaitu hijauan dicampur konsentrat kurang tepat, hal ini perlu dipertimbangkan proporsi antara konsentrat dan hijauan harus dicopper sehingga dapat tercampur homogen dimana formulasinya juga harus dapat memenuhi kebutuhan nutrisi terutama protein kasar (PK) atau bentuk DP dan energi total digestible nutrient (TDN) dan secara kasar kebutuhan bahan kering sebanyak $2-3 \%$ bobot ternak dengan proporsi $60 \%$ dari hijauan pakan dan $40 \%$ dicukupi dari konsentrat. Perhitungan penggunaan hijauan segar dan konsentrat untuk memenuhi proporsi tersebut dapat dilakukan dengan benar asalkan kandungan \% bahan kering (BK) dalam bahan pakan diketahui. Mitra peternakan sapi perah ini menggunakan tebon jagung yang masih hijau segar yang coppingannya masih panjang.

Selanjutnya penyusunan formulasi konsentrat harus benar yakni mengikuti standart nutrisi konsentrat sapi missal kandungan PK diatas 15\%, TDN diatas 65\% dan serat kasar $<20 \%$. Bahan pakan konsentrat perlu difermentasi dengan kondisi optimal baik dosis mikroba dan kelembaban bahan, Selanjutnya kotoran feses dan urine sapi dibuang ke saluran sungai kampung yang mestinya ditangani dengan baik, hal ini tim pengabdi menyarankan digunakan bahan baku pembuatan biogas menghasilkan energi gas metan untuk menyalakan lampu dan kompor gas dan limbahnya biogas sangat baik untuk digunakan sebagai pupuk organik padat dan cair sehingga perlu dibuatkan instalasi biogas skala sedang untuk menggantikan gas elpiji untuk kebutuhan kelaurga. Produksi air susu sapi masih rendah rata per ekor 10 liter/ hari dan dipasarkan bentuk segar tanpa diolah menjadi produk bervariasi Itulah profil mitra peternakan sapi perah PFH di lokasi seperti terlihat pada Gambar 1.

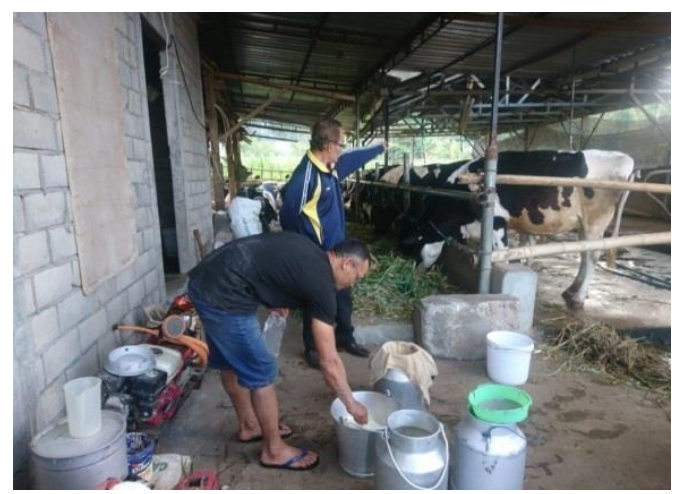

Gambar 1. Profil peternakan sapi perah

Selain itu sapi perah membutuhkan mineral terutama kalsium, natrium dari garam dapur dan pospor, dalam hal ini sapi perlu diberi pakan suplemen berupa urea molases blok (UMB) yang kaya akan mineral dan bahan bahan untuk sintesa protein dari urea sumber qsam amino dan molases. Ditinjau dari sisi gizi pakan, ternak ruminansia sapi perah dengan sistem pencernaan mikrobial di rumen retikulum maksimal, maka sapi mampu mentolerir pakan serat kasar lebih $18 \%$ dan protein kasar rendah kurang 14\% (Ensminger, Oldfield dan Heinemann, 1990). Apabila manajemen pemeliharaan sapi perah secara intensif, maka berpeluang sebagai bisnis ternak sapi perah penghasil susu yang membanggakan dan menguntungkan peternak.

Hasil diskusi dengan mitra selama observasi awal, maka tim pengabdi mendapatkan permasalahan prioritas yaitu:

1. Kurangnya beberapa sarana kandang, tidak disediakan palungan, hijauan dihamparkan di depan sapi meskipun sudah dicopper konsentrat dan air minum dimasukkan dalam ember, perlu segera.

2. Terbatasnya pengetahuan dan teknologi formualasi pakan konsentrat dan pakan 
TMR serta inovasi pembuatan pakan UMB sebagai pakan jilat sumber mineral bagi sapi perah (Soebarinoto, Chuzaemi dan Mashudi, 1991).

3. Mitra belum mengaplikasikan pola pemeliharaan sapi perah secara intensif yang mengacu pada sapta usaha peternakan yang pada prinsipnya memperhatikan breeding, feeding dan manajemen (Siregar, 1990).

4. Pembuangan feses kotoran sapi perah masih langsung ke saluran menuju sungai kampung sehingga mencemari lingkungan, perlu ditampung dahulu diendapkan dan dikeringkan untuk dijadikan bahan pembuatan pupuk organik.

Solusi yang ditawarkan untuk menyelesaikan permasalahan yang dihadapi mitra PPM ini meliputi:

1. Penanaman hijauan pakan menggunakan sistem tiga strata (STS) dalam lahan pertanian dengan tanaman gamal, lamtoro dan pohon nangka sebagai pagar, di bagian dalamnya ditanami ubi jalar, dan sayuran dan bagian paling dalam tanaman pangan jagung, padi atau tanaman kacang. Hal ini solusi mengatasi sulitnya penyediaan hijauan pakan untuk sapi perah yang membutuhkan bahan kering pakan sebanyak $2-3 \%$ bobot badan.

2. Praktek pengolahan dan pengawetan pakan baik dengan fermentasi agar kualitas pakan terkontrol.

3. Manajemen pemberian pakan yang tepat baik kombinasi hijauan pakan dan konsentrat harus sesuai kebutuhan sapi perah untuk meningkatkan produksi susu sekaligus efisiensi pakan (Tillman, dkk., 1989).

4. Sistem perkawinan dan program pembibitan untuk mendapatkan bibit unggul dengan cara upgrading bukan inbreeding

5. Pencegahan penyakit cacing melalui oral, sehingga sapi perah menjadi sehat dan produktif

6. Perbaikan sistem pemasaran susu segar melalui kerjasama dengan penjual susu segar bukan disetor ke koperasi.

\section{METODE}

Realisasi pelaksanaan program pengabdian kepada masyarakat peternak sapi perah, maka tim pengabdi menggunakan beberapa metode kegiatan pertama melakukan sosialisasi program dan reobservasi lapang, kemudian penyuluhan sapta usaha peternakan, pelatihan membuat pakan fermentasi limbah agroindustry menjadi palatabel, pembuatan pakan permen UMB plus dan model pemberian pakan total mixed ration (TMR), terakhir pendampingan dalam manajemen pemeliharaan dan penanganan kotoran sapi.

Semua pekerjaan dalam PPM ini dilakukan melalui pendekatan partisipatif, transparansi bersama mitra peternak sapi perah. Program yang dilaksanakan harus dapat dipertanggung jawabkan dalam hal ketepatan sasaran, waktu, pembiayaan, dan mutu pekerjaan sehingga kegiatan pendampingan kegiatan dalam PPM mitra peternak sapi perah ini perlu melibatkan unsur pelaksana khusus yang ahli di bidangnya.

\section{HASIL DAN PEMBAHASAN}

Pelaksanaan kegiatan PPM ini diawali dengan sosialiasi program dan reobservasi lokasi pada mitra untuk memastikan permasalahan mitra yang akan dicarikan solusi sehingga tim pengabdi lebih fokus menyelesaikan pekerjaan yang sudah disepakati bersama. Adapun beberapa kegiatan pengabdian masyarakat yang dilaksanakan dideskripsikan sebagai berikut.

\section{Penyuluhan sapta usaha peternakan}

Kegiatan penyuluhan ini dimaksudkan untuk memberikan pemahaman, dan diskusi manajemen pemeliharaan sapi perah. Dalam diskusi dapat ditemukan banyak permasalahan utama peternak dalam seluk beluk manajemen pemeliharaan sapi perah mulai dari seleksi bibit/ bakalan sapi, pakan, perkandangan, kesehatan, reproduksi, penanganan limbah dan pemasaran susu, keseluruhan itu dikenal dengan sebutan Panca usaha peternakan.

Panca dan sapta usaha peternakan sapi perah merupakan tujuh faktor penting mendukung keberhasilan usaha peternakan secara intensif yang meliputi 1). penggunakan bibit atau bakalan ternak unggul sesuai tipenya sapi perah, 2). Pemberian pakan bergizi dan dalam jumlah cukup sesuai kebutuhan sapi baik BK , protein dan energi TDN (kg) 3). Perkandangan dan sistem pemeliharaan yang benar meliputi sanitasi dan ventilasi kandang serta pemeliharaan secara koloni , 4). Melakukan sistem reproduksi dan perkawinan dengan tepat baik menggunakan inseminasi buatan atau alam dan tepat waktu tidak terlambat dan harus masih di masa birahi sehingga peternak harus mengetahui tandatanda birahi ternak ruminansia (mamalia ada 4 A yaitu Abang (merah), Aboh, Anget dan Arep serta nafsu makan menurun, 5). Pencegahan dan pengobatan penyakit, 6$)$. Penanganan saat pemerahan susu dan pengolahan produksi susu dengan baik, dan 7). Sistem pemasaran / marketing produk susu segar atau olahannya 
yang handal. Dokunetasi kegiatan ini tercantum pada Gambar 2.

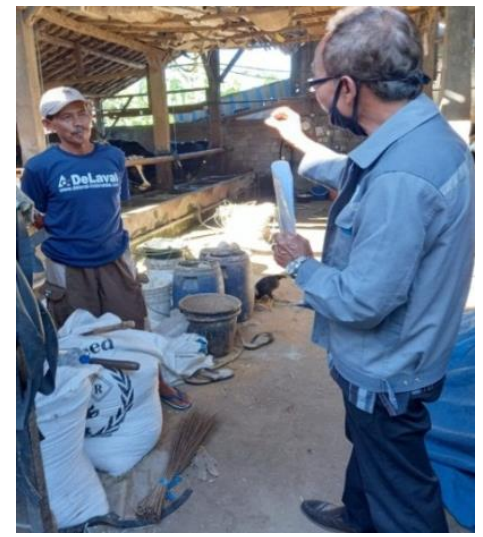

Gambar 2. Konsultasi dan diskusi

\section{Pembuatan Pakan Fermentasi}

Fermentasi pakan bertujuan untuk meningkatkan kualitas dan kandungan nutrisi sekaligus palatabel pakan karena aroma produk fermentasi pakan harum khas terutama berasal dari molases tetes tebu yang digunakan (Ali dan Wadjdi, 2014), . Pelaksanaan fermentasi menggunakan starter Inokulan bakteri produksi Fapet Unisma dengan dosis 1 liter inokulan untuk 1 kuwintal bahan pakan diinkubasikan secara anaerob selama 4-5 hari dengan kelembaban 45\%-50\%. Bahan limbah diformulasi campuran bekatul $20 \%$ : kulit daging kelapa (KDK) $20 \%$, pollard $15 \%$, ampas kecap $10 \%$, ampas tahu $20 \%$ dan onggok $15 \%$ kondisi kering. Tahap awal mencampur bahan pakan penggunaannya sedikit pada bahan yang penggunaan jumlah besar, diaduk sampai homogen.

Selanjutnya campuran bahan disiram dengan larutan starter inokulan bakteri seluloitik dosis sebanyak $10^{8}$ TPC per gram BK bahan diencerkan dengan air sampai diperkirakan campuran bahan kelembaban atau kadar air sebesar $45-50 \%$ atau bahan kering sebesar 55$50 \%$ yang ditandai kondisi mamel menggunakan rumus baku pengeringan atau pengenceran sebagai berikut: M1.C1 = M2.C2, dimana $\mathrm{M}$ massa bahan, $\mathrm{C}$ kadar bahan kering dan 1,2 kondisi awal dan kondisi akhir (Usman, Soebarinoto, Chuzaemi, Osfar, 2014). Mixing bahan seperti pada Gambar 3.

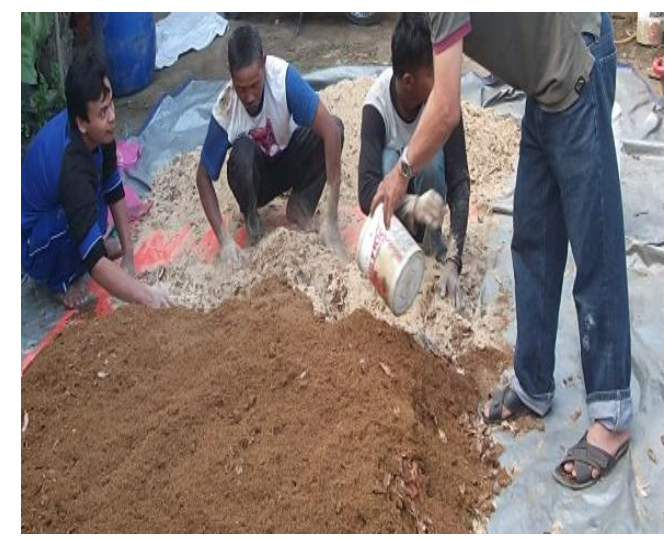

Gambar 3. Mixing bahan pakan difermentasi

Setelah bahan diaduk dibolak-balik sampai tercampur homogen, kemudian dimasukkan dalam drum plastik dan karung zak rangkap dimampatkan sampai tidak ada cela dan tidak berongga dan ditutup rapat dan diinkubasi selama 7-10 hari sudah sempurna fermentasinya seperti pada Gambar 4. Adanya pelatihan fermentasi ini berdampak dapat menekan pembiayaan pakan konsentrat karena peternak dapat membuat formulasi pakan sendiri menggunakan bahan pakan limbah agroindustri lokal yang dibeli harga murah. Adapun ilustrasi tahapan fermentasi campuran bahan pakan dan limbah kulit daging kelapa menjadi pakan konsentrat bergizi dan palatabel.:

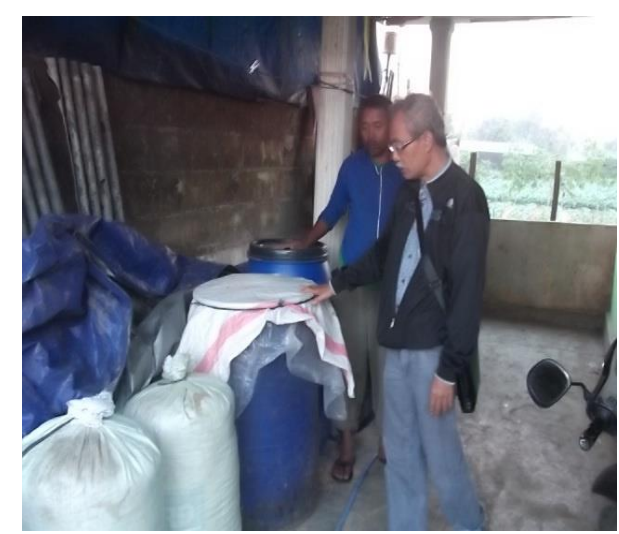

Gambar 4. Inkubasi pakan fermentasi

\section{Pembuatan Pakan Jilat UMB Plus}

Pakan Urea Molases MultiNutrien Blok (UM2NB) merupakan pakan suplemen bermanfaat untuk ternak sapi, kambing, domba (ternak ruminansia), berbentuk padat yang kaya nutrisi terutama multimineral terbuat dari bahan utama molases sebagai sumber energi, Urea sebagai sumber $\mathrm{N}$-protein, garam dapur, ultra mineral, kapur digunakan sebagai pelengkap nutrisi pakan, dan untuk mudah menyerap tetes tebu, dan bekatul, bahan pengisi dan penyerap molases dedak, konsentrat. Pakan suplemen ini disebut pakan jilat untuk ternak ruminansia. Beberapa manfaat dan keuntungan pakan UMB 
bagi usaha peternakan ternak ruminansia yaitu :

1. Merupakan sumber protein (non-protein nitrogen)., energy dan mineral yang sangat dibutuhkan ternak ruminansia.

2. Sebagai pakan tambahan (supelemen) bagi ternak yang dikandangkan atau digembalakan. 3. Dapat meningkatkan kecernaan dan konsumsi nutrisi pakan dari bahan pakan serat tinggi, sehingga produktivitas ternak meitingkat. Selanjutnya bahan komposisi pembuatan pakan UMB terdiri dari :

1. Molases merupakan komponen utama dalam pembuatan UMB. Bahan ini digunakan karena mengandung karbohidrat sebagai sumber energi dan mineral.

2. Urea, sebagai sumber nitrogen diperlukan pada proses fermentasi dalam rumen.

3. Bahan pengisi, ditambahkan agar dapat meningkatkan kandungan nutrisi pakan dan menjadikan UMB menjadi bentuk padat dan kompak. Bahan ini berupa dedak padi, dedak gandum, bungkil kelapa, bungkil biji kapuk, bungkil kedelai, ampas tebu, ampas tahu atau bahan lain murah dan mudah didapat.

4. Bahan pengeras, penambahan bahan ini dimaksudkan untuk menghasilkan UMB yang keras, bahan-bahan ini juga mengandung mineral terutama Calsium (Ca) yang cukup tinggi, bahan pengeras antara lain tepung batu kapur, semen abu.

5. Alat pencetak pakan UMB dapat dibuat dari pipa paralon dilengkapi pendorong untuk melepaskan isi

Kegiatan demo praktek pembuatan pakan permen UMB plus menggunakan bahan utama Urea dan Molases, pakan konsentrat dan mineral mix dan perekat pengeras dari semen abu dan tepung gaplek dengan formula Urea $8 \%$. Molases 20\%, konsentrat 60\%, mineral $2 \%$ dan tepung gaplek $10 \%$ seperti tercampur pada Gambar 5.

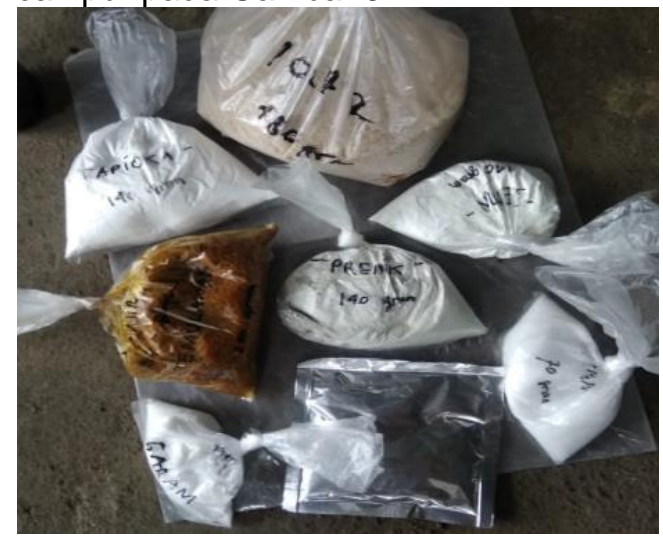

Gambar 5. Bahan \& Formulasi Pakan UM2NB

Semua bahan dicampur merata kecuali tepung gaplek ditambah semen abu 8-10\% dari campuran bahan, kemudian melarutkan tepung gaplek dalam air panas secukupnya dan dituangkan pada campuran bahan sampai adonan menjadi mamel yang selanjutnya dicetak menggunakan potongan paralon setinggi $15-20 \mathrm{Cm}$ yang dilengkapi sumbu penekan, kemudian dikeringkan udara dihindari pengeringan matahari langsung biar hasil kering kompak. Mixing bahan pakan untuk pembuatan pakan TMR seperti pada Gambar 6 .

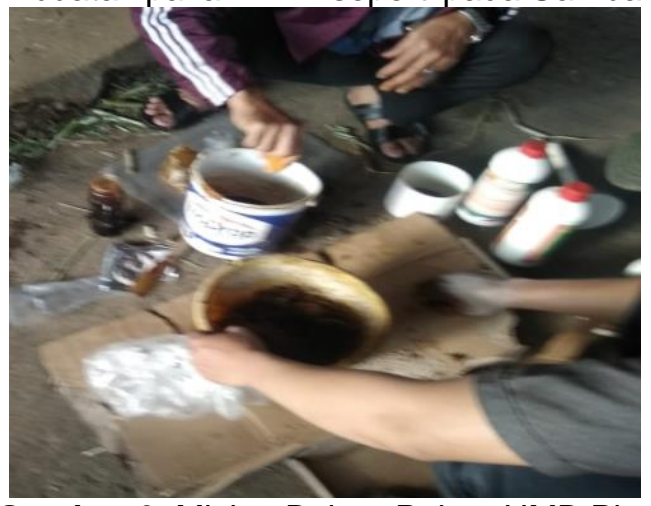

Gambar 6. Mixing Bahan Pakan UMB Plus

Penggunaan urea dan molasses dimanfaatkan mikroba rumen untuk sintesa protein, selain itu pakan jilat UMB Plus ini sangat palatable bagi sapi perah dan kaya gizi sehingga dapat mensuplementasi nutrisi terutama protein dan mineral dengan demikian akan meningkatkan produksi susu segar (Mira, et al, 2018). Selanjutnya tim pengabdi melakukan uji coba pemberian pakan jilat UM2NB pada sapi perah dan terlihat palatable seperti pada Gambar 7.

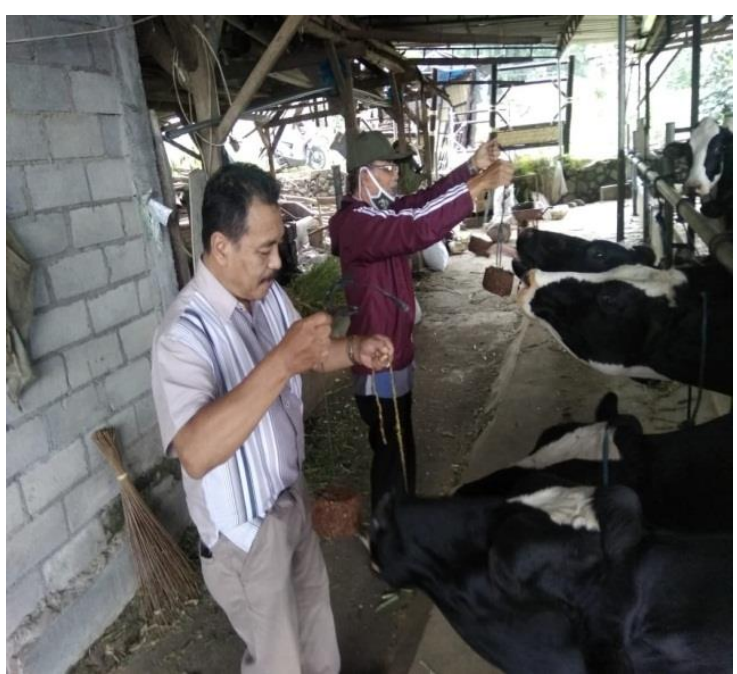

Gambar 7. Uji Coba Pemberian Pakan Jilat

\section{Pendampingan Pemberian Pakan TMR}

Kegiatan pendampingan pemberian pakan TMR, tim pengabdi memperkenalkan beberapa pedoman praktis penggunaan konsentrat dalam pakan TMR sapi perah antara lain (1). Pakan TMR sapi perah laktasi disusun dari penggunaan konsentrat sebanyak $1-2 \%$ 
dari bobot badan (BB) dan pakan hijauan segar maksimal $10 \%$ bobot nadan (BB) sapi, (2). Penggunaan konsentrat per ekor (kg/hari) sebanyak setengah dari produksi susu segar dan pemberian hijauan segar maksimal 10\% BB sapi perah, (3). Pemberian pakan TMR berdasarkan kebutuhan nutrisi minimal bahan kering (KBK) pakan sebanyak 2-3\% Bobot badan (BB) yang dibagi dalam rasio penggunaan konsentrat $40 \%$ dan pakan basal hijauan $60 \%$ ndalam bentuk BK (Adibul, Kalsum, Sumartono, 2021),

Kebutuhan BK dirumuskan sebagai produksi susu segar dibagi 1,2 dalam satuan $\mathrm{Kg}$ BK, (Astuti, dkk, 2015), (4). Penggunaan pakan TMR berdasarkan kebutuhan protein atau DP dan energi TDN yang dipenuhi dari pakan konsentrat dan hijauan segar dengan proporsi $40 \%$ dan $60 \%$ dalam bentuk BK, dimana kebutuhan PK atau TDN dapat ditentukan/ diperediksi dari standar konsumsi BK $(\mathrm{Kg})$ $\mathrm{x} \% \mathrm{PK}$ atau \%TDN dalam BK. Kemudian pakan TMR diberikan dalam bentuk asfed, dimana konsentrat bentuk kering sedang hijauan bentuk segar yang dicopper, Penghitungan jumlah bahan pakan dalam bentuk asfed menggunakan rumus konversi sebagai berikut $=$ (kebutuhan BK x 100/BK bahan pakan)

Usman (2016) menjelaskan apabila BB sapi perah laktasi $400 \mathrm{Kg}$, maka kebutuhan BK $=2,5 / 100 \times 400 \mathrm{Kg}=10 \mathrm{Kg}$ BK degan rasio penggunaan konsentrat (BK 85\% dan pakan hijauan (BK 24\%) adalah $40 \%$ atau 0,4 dan $60 \%$ atau 0,6 dari kebutuhan BK pakan, maka jumlah konsentrat asfed yang diberikan $=0,4 \times 10 \mathrm{Kg} x$ $100 / 85=4,51 \mathrm{Kg}$ sedangkan julah pemberian hijauan segar $=0,6 \times 10 \mathrm{Kg} \times 100 / 24=25 \mathrm{Kg}$. Namun sebenarnya kebutuhan nutrisi bagi sapi perah bukan hanya mengacu pada pemenuhan kebutuhan nutrisi BK saja tetapi ditekankan pada jumlah kebutuhan $\mathrm{Kg}$ protein kasar (ebih baik lagi $\mathrm{DP}$ ) atau $\mathrm{Kg}$ energi TDN.

Penggunaan konsentrat $40 \%$ dalam pakan TMR dapat meningkatkan kualitas susu yang dihasilkan dengan kandungan SNF, Laktosa dan lemak susu turun yang lebih tinggi daripada penggunaan kurang dari $40 \%$ (Putra, Ali dan Muwakhid, 2021). Namun demikian Tim pengabdi menyarankan peternak untuk menggunakan pedoman praktis dan mudah yaitu jumlah pemberian konsentrat sebanyak setengah produksi susu segar sedang hijauan segar sejumlah $10 \%$ bobot badan sapi perah laktasi.

\section{SIMPULAN DAN SARAN}

Disimpulkan bahwa program
pengabdian masyarakat bagi mitra peternak
sapi perah sasaran meliputi kegiatan
penyuluhan memahami unsur panca usaha

peternakan, Belajar dan praktek membuat pakan fermentasi dari limbah agroindustri lokal, Demo praktek pembuatan pakan jilat UMB plus sebagai pakan suplemen bagi sapi dan diakhiri pendampingan usaha dan pemberian pakan TMR mencukupi kebutuhan nutrisi bagi sapi sehingga dapat meningkatkan produksi susu segar menjadi 18 liter/ekor/hari yang semula sebanyak 16 liter/ekor/hari. Semua kegiatan yang dilakukan tim pengabdi direspon peternak dengan baik dan tetap dibuka konsultai yang terkait untuk pengembangan peternakan sapi perah lebih intensif lagi,

Selanjutnya disarankan peternak sapi perah hendaknya terus mengembangkan usahanya menuju peternakan intensif dengan selalu memperhatikan dan mengacu pada sapta usaha peternakan sehingga produksi susu normal dengan kualitas susu sesuai standar SNI susu segar

\section{UCAPAN TERIMAKASIH}

Tim Pengabdi mengucapkan terima kasih kepada LPPM UNISMA dan Dekan Fakultas Peternakan Universitas Islam Malang yang telah memfasilitasi dan memberi dana Hima Tahun anggaran 2020/2021 skim Pengabdian Masyarakat sehingga kegiatan dapat terlaksana dengan baik

\section{DAFTAR RUJUKAN}

Adibul, M., Kalsum, U., dan Sumartono.(2021). Pengaruh Rasio Penggunaan Konsentrat dan Hijauan Tebon Jagung Dalam Pakan Total Mixation Ratio Terhadap Produksi Dan Berat Jenis Susu Segar Sapi Perah Peranakan Friesian Holstein Laktasi. Skripsi Fakultas Peternakan, UNISMA. Malang

Ali. U dan Wadjdi, M.F. ( 2014), Pemanfaatan Bakteri Selulolitik Sekum Kelinci dengan Aras Konsentrasi Koloni dan Waktu Inkubasi untuk Fermentasi Limbah Agroindustri Lokal dalam Pakan Kelinci. Sains Peternakan. Jurnal penelitian IImu Peternakan. UNS 2548-9321

https://jurnal.uns.ac.id/Sains-

Peternakan/article/view/4780.

Ali, U. (2016). Pedoman Praktikum IImu Nutrisi Ternak Dasar, Fakultas Peternakan, Universitas Islam Malang

Astuti, A., Erwanto dan E.S. Purnama. (2015). Pengaruh Cara Pemberian Konsentrat dan Hijauan Terhadap Respon Fisiologis Dan Performan Sapi Peranakan Simmental. Jurnal IImiah Peternakan Terpadu Vol 3. No. $4: 201$ 207. 
Chuzaemi, S., Natsir,M.H, Sjofjan,O., Muttaqin, A., Nuningtyas, Y.F. dan Huda, A.N. UMMB Temulawak (Curcuma xanthorrhiza) Sebagai Suplemen Pakan Ternak Ruminansia. Jurnal Nutrisi Ternak Tropis. Vol $3 \mathrm{~N}$ o $1 \mathrm{pp}$ 23-29

Ensminger, M.E., J.E. Oldfield, and W.W.Heinemann. (1995). Feed and Nutrition The Ensminger Publishing Company, California (Buku Penulis 3)

Mardikanto, T. 2009. Sistem Penyuluhan Pertanian. Pusat Pengembangan Agribisnis dan Perhutanan Sosial Sebelas Maret University Press. Surakarta.

Mira, P., Wan Zahari, M., Rusli, N. D., and Mat, K. (2018). Effects of non-medicated nutrient blocks on dry matter intake, growth performance, body condition score and feed conversion ratio of saanen lactating does fed conventional diets. Tropical Agricultural Science, 24(2), 729-740.

Puta, M.S., Ali, U., dan Muwakhid, B..(2021). Pengaruh Penggunaan Konsentrat Dalam Pakan Total Mixed Ration Terhadap Kandungan Lemak, Laktosa, dan Solid Non Fat Susu Segar Sapi Perah.Skripsi Fakultas Peternakan, UNISMA. Malang

Soebarinoto, S. Chuzaemi dan Mashudi. (199I). IImu Gizi Ruminansia. Uiversitas Brawijaya. Animal Husbandry Project Malang. (Buku Penulis 3) Siregar, S. 1990. Sapi Perah: Jenis, Teknis Pemeliharaan dan Analisis Usaha Penerbit Swadaya. Jakarta (Buku Penulis 1)

Tillman, A.D., H. Hartadi, S. Reksohadiprodjo, Prawirokusumo dan Lebdosoekojo. (1989). Ilmu Makanan Ternak Dasar. Fakultas Peternakan Universitas Gadjah Mada Gadjah Mada University Press.Yogyakarta. (Buku Penulis 5)

Wulandari, Z., Taufik, E., dan Syarif, M. (2017). Kajian Kualitas Produk Susu Pasteurisasi Hasil Penerapan rantai Pendingin. Jurnal Ilmu Produksi dan Teknologi Hasil Peternakan, 5(3), 94100.

Usman, A. (2017). Modul Praktikum IImu Nutrisi Pakan Ternak Ruminansia. Fakultas Peternakan, Universitas Islam Malang.

Usman, A., Soebarinoto, Chuzaemi, S., Osfar,S. (2014). The Effect Fermentation of Local Agroindustry Waste Using Cellulolytic Bacteria Cellulomonas on Nutrient Content as 